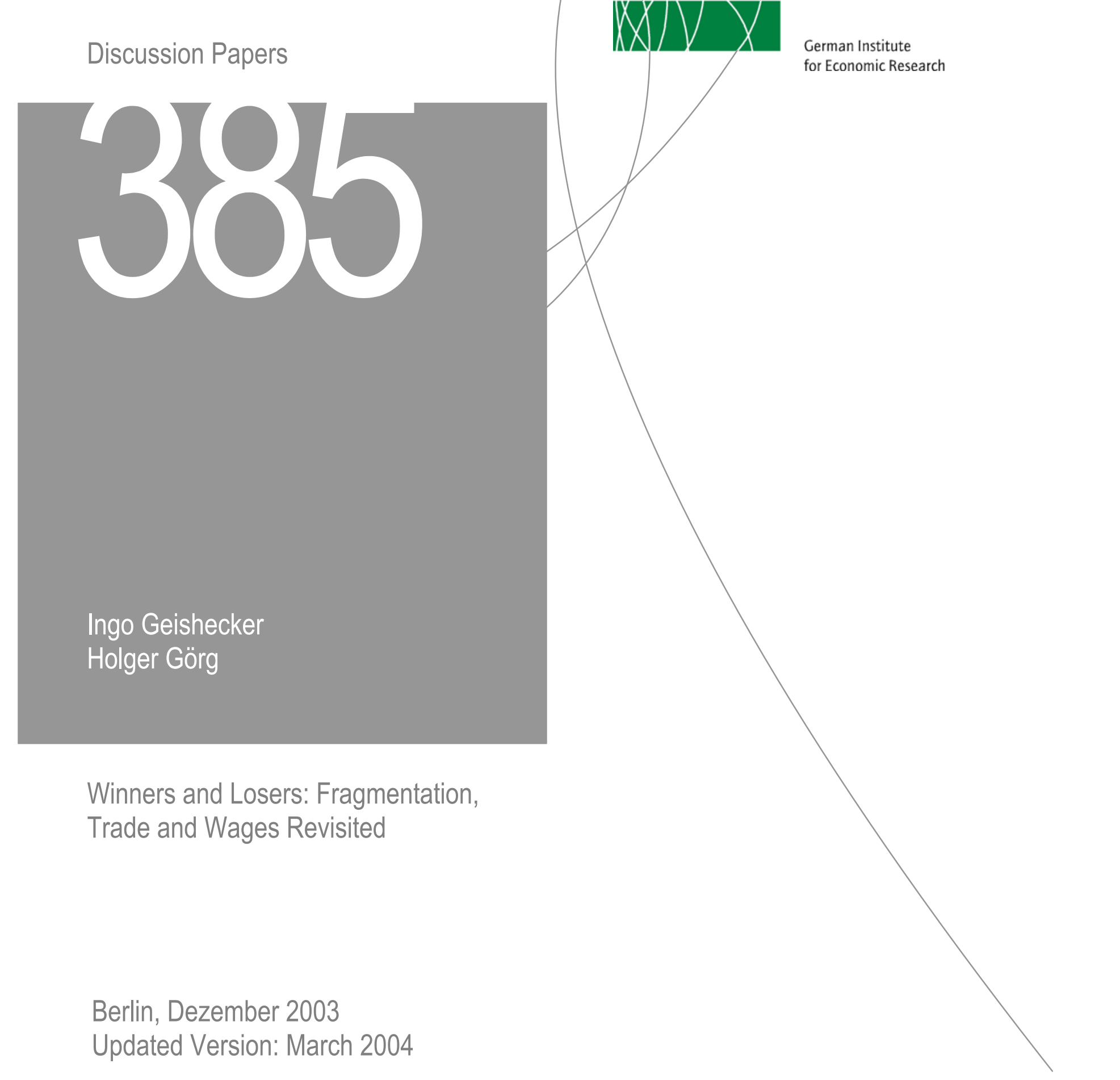


Opinions expressed in this paper are those of the author and do not necessarily reflect views of the Institute.

DIW Berlin

German Institute

for Economic Research

Königin-Luise-Str. 5

14195 Berlin,

Germany

Phone +49-30-897 89-0

Fax $\quad+49-30-89789-200$

www.diw.de

ISSN 1619-4535 


\title{
Winners and Losers: Fragmentation, Trade and Wages Revisited (Updated Version)
}

\author{
Ingo Geishecker (DIW BERLIN) \\ Holger Görg (University of Nottingham) *
}

March 2004

\begin{abstract}
Our paper investigates the link between international outsourcing and wages utilising a large household panel and combining it with industry level information on industries' outsourcing activities from input-output tables. By doing so we can arguably overcome the potential aggregation bias as well as other shortcomings that affect industry level studies. We find that outsourcing has had a marked impact on wages. Distinguishing three skill categories we find evidence that outsourcing reduced the real wage for workers in the lowest skill categories by up to $1.8 \%$ while it increased real wages for high-skilled workers by up to $3.3 \%$. This result is robust to a number of different specifications.
\end{abstract}

Keywords: Outsourcing, Fragmentation, Skills, Wages

JEL: F16, L24, J31

* Earlier versions of the paper were presented at a workshop at Claremont McKenna College and seminars at Zurich and Birmingham. The authors are particularly grateful to Mitsuyo Ando, Alan Deardorff, Peter Egger, Josef Falkinger, Edward Leamer, Matt Slaughter, Eric Strobl, Rainer Winkelmann and Peter Zweifel for helpful comments. Furthermore we thank John Haisken-DeNew for providing us with a test version of his data retrieval tool "SOEP Menu". Holger Görg gratefully acknowledges financial support from the Leverhulme Trust (Grant No. F114/BF). 


\section{Introduction}

Outsourcing is a growing phenomenon in world trade and has sparked a lot of interest in the recent academic literature and business press. As for the car industry, the Economist (23 February 2002, p. 99) writes that: "The whole industry is disintegrating (or becoming less vertical) as vehicle assemblers try to outsource more and more of what they once did for themselves." There is plenty of anecdotal evidence that this is not limited to the car industry but is also observed in other manufacturing and services sectors. ${ }^{1}$

Hummels, Ishii and Yi (2001) provide evidence for the worldwide importance of outsourcing from data collected for $10 \mathrm{OECD}$ and four emerging market countries. They find that trade in outsourced components in the vertical production chain accounts for around 21 percent of these countries' exports. Moreover, international outsourcing grew very strongly by approximately 30 percent between 1970 and $1990 .^{2}$

Given that the increase in international outsourcing coincided with deteriorating relative wages and employment chances for low skilled workers in many developed countries much research has been devoted to assess the impact of this disintegration of production on domestic labour markets (see Feenstra and Hanson, 1996, 1999 and Morrison-Paul and Siegel (2001) for the US, Hijzen, Görg and Hine (2002) and Hijzen (2003) for the UK and Geishecker (2002) for Germany). ${ }^{3}$ Most studies that investigate the impact of international outsourcing do so by estimating the relative demand for skilled labour derived from a cost function, or mandated wage regressions using aggregate industry or country level data. In a sense this is quite unsatisfactory, as outsourcing has implications for micro units (firms or workers) which should arguably be studied using micro level data in order to avoid aggregation bias. A notable exception in this literature is the recent work on Japanese micro level data by Head and Ries (2002) which examines the impact of outsourcing on relative labour demand. They find that an expansion of employment in affiliates in low income countries (which can be taken as a proxy of international outsourcing of low skill production) raises the skill intensity of domestic production. ${ }^{4}$

\footnotetext{
${ }^{1}$ For example, Jones and Kierzkowski (2001) provide examples from IT, car manufacturing, sport shoe manufacturing etc.

${ }^{2}$ See also Feenstra (1998) for a discussion of the growth of outsourcing or fragmentation of production.

${ }^{3}$ There have also been studies for other countries. See Feenstra and Hanson (2001) for a concise review of this literature. The papers on labour market effects of outsourcing are of course related to the wider debate on the effects of trade and technology on wages, see Leamer (1998), Freeman (1995), Krugman (1995), Berman, Bound and Machin (1998).

${ }^{4}$ Note, however, that they measure outsourcing in terms of offshore employment rather than imported inter-
} 
Our paper investigates the link between outsourcing and wages from a different perspective utilising a large household panel and combining it with industry level information on industries' outsourcing activities from input-output tables. Hence, we directly assess the effects of international outsourcing on wages at the level of the individual. By doing so we can arguably overcome the potential aggregation bias as well as other shortcomings that may affect industry level studies. Furthermore, we extend the literature by employing three different definitions of workers' skill levels. Usually, the literature just considers one definition; the most common definition being based on production vs non-production workers, see, e.g., Feenstra and Hanson (1996) and Berman et al. (1998).

Our empirical analysis uses data from the large German Socio-Economic Household Panel, which is described in some detail below, combined with industry level data for the period 1991 to $2000 .^{5}$ The literature analysing the labour market impact of international trade in a household panel framework is sparse and studies more specifically assessing the impact of international fragmentation on the earnings distribution in the context of individual wage models are, to the best of our knowledge, not existing. ${ }^{6}$ Germany is an interesting case to analyse, as there is a general consensus that relative wages of high vs. low skilled workers have remained virtually unchanged since the 1980s, even though fragmentation of activities has increased substantially during the 1990s, probably aided by the opening up of low wage Eastern and Central European markets which provided potential for fragmentation. ${ }^{7}$

Against this background of nearly constant relative wages on aggregate, we find from our individual level data that international outsourcing has, nevertheless, had a marked impact on wages. Distinguishing three skill categories we find evidence that outsourcing reduced the real wage for workers in the lowest skill categories; the results are similar in terms of magnitude, if not statistical significance, across the three definitions of skill groups. Furthermore we find evidence that high-skilled workers experienced increased wages due to international outsourcing for all three skill definitions.

mediates, as in our paper and in most of the related literature.

${ }^{5}$ See Hunt (2001), Burda and Mertens (2001) and Krueger and Pischke (1995) for analyses using this data set in different contexts.

${ }^{6}$ Haisken-DeNew and Zimmermann (1999) estimate the impact of trade on real wages for different skill groups and various measures of labour market mobility combining data from the German Socio-Economic Household Panel and industry level data for the period 1985-1991. Their results of a random effects model indicate that an increase in the trade deficit ratio lowers real wages for low-skilled as well as for high-skilled workers by a comparable amount. Hence, there is no indication of a skill bias in the wage impact of international trade.

${ }^{7}$ See the recent series of articles in the German business paper Handelsblatt under the heading "Globalisierung, neuester Stand" in the issue of 2 September 2003. 
The remainder of the paper is structured as follows. Section II reviews briefly the theoretical and empirical literature on outsourcing, fragmentation and labour markets. Section III highlights recent labour market trends and motivates our empirical study. Section IV introduces the empirical model and discusses the data set. Section VI presents the empirical findings and section VII concludes.

\section{International outsourcing and wages}

The causes and consequences of outsourcing and fragmentation of production have attracted considerable interest in the theoretical literature. While papers like Feenstra and Hanson (1996) and Kohler (2003) stress the importance of international differences in relative prices as driving force of outsourcing, Jones and Kierzkowski (2001) and Harris (2001), for example, focus on the role of exogenous reductions in general services and telecommunications costs for allowing outsourcing to occur. The consequences of outsourcing for local labour markets are not clear cut in theory, depending on the models and assumptions chosen, outsourcing of the low skill intensive part of production can lead to decreases or increases in the wage of (unskilled) labour in the fragmenting economy (see, for example: Feenstra and Hanson (1996), Arndt (1997), Arndt (1999), Venables (1999); Jones and Kierzkowski (2001), Kohler (2004)). Whether workers in practice gain or lose from fragmentation is, therefore, largely an empirical question.

One of the first systematic empirical studies on the labour market impact of international outsourcing is Feenstra and Hanson (1996). In their study for the United States they estimate a factor share equation for an industry panel of more than 400 industries. In the model international outsourcing, approximated by the industries' import penetration ratios, is implemented as a shift parameter similar to technological progress. Following this procedure, the authors report that approximately $15 \%$ to $33 \%$ of the increase of the cost share of non-production labour over the period 1979-1987 can be explained by international outsourcing. In a follow-up study Feenstra and Hanson (1999) apply a narrower definition of international outsourcing by focusing on imported intermediate inputs of an industry from the same industry abroad. According to this study international outsourcing can explain between $11 \%$ and $15 \%$ of the observed decline in the cost share of production labour in U.S. manufacturing between 1979 and 1990. Morrison-Paul and Siegel (2001) extend the above studies by simultaneously incorporating several trade and technology related measures that can shift relative labour demand in a system of factor demand equations. Their results suggest that international outsourcing as well as trade and technological change significantly 
lowered relative demand for low-skilled labour.

The above studies have in common that international outsourcing is assumed to be exogenous to the industry, hence international outsourcing is no "choice factor" (Morrison-Paul and Siegel (2001) p. 245). This assumption could in principle be criticised since, at least to some degree, international fragmentation is an industry's choice variable, and relative labour demand and the extent of fragmentation are then determined simultaneously.

Falk and Koebel (2002) propose an approach that in principle overcomes endogeneity bias in industry level studies. Using a Box-Cox cost function, which nests the normalised quadratic as well as the translog functional form, they estimate elasticities of substitution from a system of input-output equations. Outsourcing is implemented in the model as a flexible choice variable captured by relative prices for imported intermediate goods and purchased services. Their findings suggest that between 1978 and 1990 neither imported material inputs nor purchased services substitute for unskilled labour in German manufacturing industries. ${ }^{8}$

This approach can be criticised from a theoretical point of view since the impact of international outsourcing is only captured by relative price changes for intermediate inputs that are actually traded. However, intensified international outsourcing is consistent with unchanging or even increasing relative prices for imported intermediate inputs as they are revealed by trade statistics. The driving forces behind international outsourcing are not necessarily the dynamics of relative prices but exogenous factors such as trade liberalisation, the opening up of former communist states or new advances in communication technologies that enable firms or industries to economise on absolute cost differentials between domestic and foreign production at any fixed point in time (see Wood (2002), Jones and Kierzkowski (2001), Harris (2001)). ${ }^{9}$

Our approach differs significantly from the previous empirical studies and may be considered suitable to overcome the shortcomings discussed above. Utilising a large household panel, we incorporate the industry's international outsourcing activity as a shift parameter in a Mincerian (Mincer (1974)) wage model. This approach has substantial advantages over an industry level analysis, as it allows controlling for individual observed and unobserved heterogeneity thereby avoiding aggregation bias. In addition, changes in relative earnings can now be decomposed into wage gains and losses for different skill groups. Furthermore, since

\footnotetext{
${ }^{8}$ Another solution to this problem could be to instrument for international outsourcing. However, it is difficult to find valid instruments. See Morrison-Paul and Siegel (2001) and Hsieh and Woo (2003) for applications.

${ }^{9}$ The problem is that the reduction in obstacles to outsourcing such as trade barriers or high communication costs is not necessarily reflected in declining prices for traded intermediates, as there might have been initially no or much less trade with intermediates.
} 
the industry's outsourcing activities may be largely considered exogenous to the individual, endogeneity bias due to simultaneous determination of labour demand and international outsourcing at the industry level may arguably be to some extent reduced.

Given the nature of our econometric estimation our results should be interpreted as the short run effects of international outsourcing on wages of individuals within industries. Hence, we can think of our approach as essentially partial equilibrium, in line with the theoretical one sector setting of, e.g., Feenstra and Hanson (1996). This is consistent with a short run view of the economy such that labour is immobile between industries. Many previous empirical studies implicitly or explicitly make the same assumption (Feenstra and Hanson (1996), Morrison-Paul and Siegel (2001), Hsieh and Woo (2003)).

In line with Feenstra and Hanson (1996) and Feenstra and Hanson (1999) we construct two measures of international outsourcing (OUT) applying a narrow and a wide definition such that:

$$
\begin{aligned}
O U T_{j t}^{\text {narrow }} & =\frac{I M P_{j t}}{Y_{j t}} \\
O U T_{j t} \text { wide } & =\frac{\sum_{j=1}^{J} I M P_{j t}}{Y_{j t}}
\end{aligned}
$$

with $\mathrm{j}$ denoting the respective two-digit manufacturing industry $(j \in J), I M P$ the value of imported intermediate inputs from a foreign industry and $Y$ the industry's output value. Hence, narrowly defined outsourcing only captures an industry's imported intermediate inputs from the same industry abroad while widely defined outsourcing incorporates all imported intermediate manufacturing goods of an industry.

\section{Recent labour market trends and international outsourcing}

It is well established that relative earnings of low skilled workers have decreased in most OECD countries during the last two decades. However, wage trends are far from uniform across countries with the US and Great Britain experiencing very strong increases in the wage dispersion, and countries such as Australia, Canada, Japan and Spain only experiencing modest decreases in the relative earnings of low skilled workers (see Freeman and Katz (1995), OECD (1994) for a detailed discussion).

In this study we focus on the German labour market which is an interesting case since it is not only the largest economy in Europe, but it is also far more open to international trade than for instance the U.S. and has a fairly rigid labour market. Furthermore political and economic transition in the former communist Central and Eastern European countries 
(CEEC's) during the 1990's now allows for intensive production sharing with these economies at Germany's doorstep with potentially large implications for the German labour market. Nonetheless, considering the wage distribution in Germany, abundant empirical evidence suggests that relative wages of the low skilled have virtually not changed or have even increased since the 1980's (see Abraham and Houseman (1995), Fitzenberger (1999), Prasad (2000), Beaudry and Green (2000)). ${ }^{10}$

Against this background international outsourcing in German manufacturing has grown substantially. Figure 1 shows the development of international outsourcing during the 1990's for the manufacturing industry as a whole. As can be seen, narrowly defined international outsourcing (as in equation 1) increased by around 60 percent between 1991 and 2000 while widely defined outsourcing grew somewhat slower by 45 percent over the same period. Figure 2 shows the evolvement of international outsourcing by two digit NACE industries. Even though international outsourcing is of very different importance for the separate industries and the dynamic patterns vary considerably almost every industry shows significant growth in the outsourcing activity.

Thus, constant relative earnings for low-skilled workers coincide with pronounced increases in international outsourcing which at first sight casts doubt on a connection between relative earnings and outsourcing. However, relative earnings can be determined by a whole range of demand and supply factors that might cancel each other out. A thorough analysis of the impact of international outsourcing on the wage distribution therefore requires simultaneous controlling for other important determinants of the wage structure.

\section{The Empirical Model}

In order to analyse more rigorously the impact of international outsourcing on wages we estimate variants of the following log wage equation:

$$
\begin{aligned}
\ln W A G E_{i j t} & =\alpha+\beta D E M O G_{i t}+\gamma W O R K_{i t}+\delta E D U C_{i t} \\
& +\theta I N D_{j t}+\lambda O U T_{j t}+\tau_{j}+\mu_{t}+\iota_{i}+\epsilon_{i t}
\end{aligned}
$$

where $W A G E_{i j t}$ denotes individual i's monthly wages in industry $\mathrm{j}$, which are defined in the next section below.

\footnotetext{
${ }^{10}$ Our own analysis on the basis of the German Socio-Economic Panel for the years 1991-2000 also fails to identify significant changes in the earnings distribution between different skill groups, which is in line with the literature.
} 
We apply control variables that are standard in such wage regressions, see for example Mincer (1974), Brown and Medoff (1989), Schmidt and Zimmermann (1991). DEMOG denotes the demographic control variables for age, marital status, geographic region. The second set of control variables (WORK) contains characteristics related to the workplace such as size and ownership of the firm, tenure, occupational category. A third set of control variables $(E D U C)$ contains educational dummies for high education (edhigh) and medium (edmed) education, low education (edlow) is the omitted category. We also control for time changing industry characteristics $(I N D)$ by including industry output and two types of capital (plant and equipment). Furthermore, we incorporate two measures to control for the effects of technological change: First, we include the industry's research and development intensity, as in, e.g., Machin and Reenen (1998). Also, to allow for further technological change effects at industry level not captured in the research and development variable we include an industry specific time trend.

We subsequently incorporate a narrow and a wide definition of international outsourcing $(O U T)$ as in equation 1 and 2. The error term is decomposed into general industry specific effects $\left(\tau_{j}\right)$ and general time specific effects $\left(\mu_{t}\right)$ which we estimate with a full set of industry dummies and time dummies respectively. This also enables us to control extensively for time invariant industry level wage determinants other than those captured by our outsourcing variable $(O U T)$ and the additional time varying industry variables. Furthermore the general time dummies also capture manufacturing wide effects such as technological progress and business cycles. We also allow for individual fixed effects $\left(\iota_{i}\right)$ that take account of unchanging observable and unobservable individual characteristics. ${ }^{11}$ The remaining error term $\left(\epsilon_{i t}\right)$ is assumed to be normally distributed.

Combining individual and industry level data could give rise to contemporaneous correlation that results in distorted standard errors as discussed in Moulton (1990). As has become standard in the literature we therefore adjust the standard errors to allow for an unspecified correlation of error terms across individuals within the same industry. One further potential problem casting doubt on the validity of our results could arise from sample selection as low-skilled workers are more likely to lose their jobs. ${ }^{12}$ However sample selection bias only occurs if selection is correlated with the idiosyncratic error term. This is unlikely in our case, since we control for a wide range of observable as well as unobservable characteristics. Nevertheless we test for that hypothesis implementing the simple procedure suggested

\footnotetext{
${ }^{11}$ Random effects were rejected in a Hausman specification test.

${ }^{12} \mathrm{~A}$ fact that is fairly well established in the literature (see Reinberg and Hummel (2002)) and that we can also confirm with our data.
} 
by Wooldridge (2002) in Chapter 17.7.1. This test allows us to reject correlation between selection and the idiosyncratic error term.

Equation (3) constrains all coefficients to the be same across skill groups. In order to relax these restrictions we also estimate the equation for each and every skill group separately.

\section{Data}

The analysis is based on data from Sample A and $\mathrm{E}^{13}$ from the German Socio Economic Panel (GSOEP) for the years 1991 to 2000 (see Haisken-DeNew and Frick (2003) for a detailed description of the panel).

Our sample is restricted to prime age (18 to 65 years) male blue and white collar workers in full time employment over the whole period in the manufacturing industry (NACE 1536). In order to maximize the number of observations, we choose an unbalanced design of the sample. The sample therefore covers 1613 individuals yielding a total number of 5268 observations. In order to avoid selection bias with respect to item non-response that might be not completely at random each explanatory variable was supplemented with a dummy for missing values. Subsequently missing values where recoded to zero and the generated dummies for missing values also act as regressors in the model. ${ }^{14}$

Wages are defined as average hourly gross labour earnings over the year preceding the respective interview month. Gross yearly wages and yearly working hours are derived from the CNEF equivalent files. Observations with missing wage information were excluded from the sample, hence we disregard observations with imputed wage information in the subsequent analysis. ${ }^{15}$

We apply three different skill definitions that only partly overlap. A description of the alternative skill groupings can be found in Table 1. Firstly, we differentiate between three different skill groups based on information on educational attainment and vocational training. Secondly, we utilise internationally comparable information following the International Standard Classification of Education (ISCED) $)^{16}$ to derive a somewhat different skill differentiation. Thirdly, we apply an alternative skill grouping based on the respondents information on the qualification that their current job actually requires. Applying this alternative skill

\footnotetext{
${ }^{13}$ Respondents from the foreigner, the immigrant and the East-German sample are therefore excluded.

${ }^{14}$ In general these coefficients are only reported if statistically significant.

${ }^{15}$ Frick and Grabka (2003) describe the imputation procedure for missing wage information. Since the procedure does not use industry level information, heterogeneity in the wage distribution with respect to industry level variables, particularly outsourcing, is reduced preventing the use of imputed data for our analysis.

${ }^{16}$ see UNESCO (1997).
} 
grouping is an interesting extension since it takes account of the actually demanded qualification by employers as opposed to the supplied qualification by employees.

Table 2 shows the skill structure, based on educational attainment, within each manufacturing industry and the employment share of the respective industry.

Industry level data on international outsourcing were obtained from input-output tables by the German Federal Statistical Office. Intermediate inputs corresponding to narrowly defined international outsourcing are represented by the main diagonal of the input-output matrix for imports. Intermediate inputs corresponding to the wide definition are represented by the column sum of imported intermediate inputs from manufacturing industries. Data on industry output and plant and equipment were obtained from the German Federal Statistical Office. Research and development investment data were obtained from the OECD ANBERD data base which provides data at the two digit (ISIC rev. 3) level for the years 1995 onwards. Research and development investment at the two digit level for earlier years was imputed with a linear trend.

\section{Results}

The results of estimating equations (3) and (4) using a fixed effects estimator to allow for time invariant individual specific effects and applying the first skill definition ${ }^{17}$ are reported in Table 3. The regressions also include a full set of regional dummies ${ }^{18}$ and time dummies as well as a full set of time fixed industry dummies and industry specific linear trends. Note that the coefficients on the individual and firm level variables are largely as expected: Age and tenure are positively related with wages (in a non-linear fashion for the former variable) and wages also increase for married workers and with the educational attainment. We also find that workers in small firms on average receive lower wages than in large (size $>2000$ employees is default category) firms, reflecting the common finding of a firm size-wage effect (Brown and Medoff (1989)).

The variable of most interest to us is, of course, the measure of international outsourcing. Column (a) reports results for the narrow measure of outsourcing as defined in equation (1), while column (c) is for the wide measure as in equation (2). As can be seen, in these regressions we find statistically insignificant negative effects of international outsourcing on wages. After allowing for different coefficients across skill groups, the outsourcing coefficients

\footnotetext{
${ }^{17}$ see Table 1

${ }^{18}$ The regional dummies are defined for each of the old West German federal states (Länder) plus one dummy capturing all new East German states.
} 
remain negative for all skill groups and are statistically insignificant with the exception of the wide measure of outsourcing for low skilled workers (3, columns b and d).

We now relax the assumption of equal coefficients across different skill groups by estimating the model separately for each and every skill group ${ }^{19}$. Hence, we allow for differences in the wage determination for different skill groups. Again we incorporate a full set of regional dummies, year dummies, industry dummies and industry specific time trends. Table 4 depicts the estimation results with narrowly and widely defined outsourcing for each skill group. Notably, the coefficients on the individual and firm level variables differ significantly between the estimations for the different skill groups. Constraining the coefficients to be uniform across skill groups therefore indeed seems not appropriate. ${ }^{20}$

With regard to the impact of outsourcing the coefficients also differ substantially from the previous specification (compare Table 3 and Table 4). For high-skilled workers the coefficient of narrowly defined outsourcing is now found to be statistically significant and positive with a one percentage point increase in the outsourcing intensity ceteris paribus yielding a positive wage premium of about 2.5 percent. A similar effect is found for widely defined outsourcing (see Table 4 columns a and d). Hence, international outsourcing appears to raise the wage for high skilled workers, a finding that is in line with the idea that firms outsource the low skill intensive parts of production and, hence, increase the relative demand for skilled workers. For medium- and low-skilled workers we find negative coefficients on the outsourcing intensity, which is also in line with this reasoning. However, these coefficients are not statistically significant. ${ }^{21}$

In order to check how robust this result is to alternative skill definitions, we apply the two alternative skill measures based on ISCED classifications and required qualifications for the respondents current job (see section $\mathrm{V}$ and Table 1) and estimate the impact of narrow and wide outsourcing for each skill group.

Applying the skill grouping in line with the International Standard Classification of Education (ISCED) we again find positive coefficients on outsourcing for high skilled workers, suggesting magnitudes similar to those found in the previous specification. In this specifica-

\footnotetext{
${ }^{19}$ applying the first skill definition as in Table 1

${ }^{20}$ This is also confirmed more formally by an F-test that rejects the parameter constraints.

${ }^{21}$ As a means of comparison we have also estimated our model including industries' import penetration calculated as imports from OECD countries and imports from non-OECD countries over gross production. As Anderton and Brenton (1999) state, particular import penetration from non-OECD countries can arguably be considered as measuring the outsourcing of low-skill intensive production to low-wage locations. However, in our regressions the coefficients of import penetration are always estimated to be statistically insignificant indicating the irrelevance of import penetration for wages.
} 
tion we now also find statistically significant and negative impacts of outsourcing on wages of low-skilled workers, suggesting reductions in wages by about 1.2 percent following a one percentage point increase in the industry's outsourcing intensity. We still fail to find any statistically significant effects on medium-skilled workers, however (see Table 5).

The results for the skill definition based on required education further support these findings. International outsourcing, both for the narrow and wide definition has a statistically significant positive impact on workers who report that their job requires a college or technical school training. For example, a one percentage point increase in the narrow outsourcing intensity ceteris paribus raising wages by about 2.4 percent. For workers with lower required qualifications we find a statistically significant negative effect of outsourcing with a one percentage point increase in narrow outsourcing yielding a wage loss of around 1.5 percent, all other things equal (see Table 6).

In order to get a better idea of the economic significance of the coefficients we perform simulations based on the statistically significant results in Table 3 to 6 . For the simulations we firstly use the estimation results in the tables to predict the expected wage for our sample. We then use the same regression results and data to obtain a prediction in which we constrain the outsourcing variable to the value of 1991. Hence, this prediction can be interpreted as showing the hypothetical average wage for the sample with constant outsourcing. The difference between these two predictions can be interpreted as the wage effect of international outsourcing.

The comparisons of the standard prediction and the prediction without outsourcing are plotted in Figures 3 to 13 for the two measures of outsourcing and the various skill definitions. $^{22}$ In Figure 6, for example, the plots illustrate that in our sample of prime age, full time working men hourly wages for the average high-skilled manufacturing worker would have been approximately 3 DM less in 2000 if there had been no increase in narrow outsourcing activity since 1991. For low skilled workers, the wage loss following narrow outsourcing was about $0.2 \mathrm{DM}$ in the same year (see Figure 7). Wide outsourcing has an effect of similar magnitude for high skilled workers (Figure 8), however, the effect of wide outsourcing for low skilled workers is higher than for narrow outsourcing at about 0.5 DM per hour. The predicted effects are in the same direction in all diagrams, it is notable, however, that the magnitude of the wage change related to outsourcing depends on the actual variable used to calculate the level of outsourcing.

Another interesting pattern in the diagrams is that the predicted lines cross, suggesting,

\footnotetext{
${ }^{22}$ We only show predictions of the point estimates if statistically significant. Of course, we could also construct confidence intervals for the predictions but for the sake of clarity of the diagrams we refrain from plotting these.
} 
for example in Figure 6, that wages for high skilled workers would have been higher without outsourcing in the early 1990s. This pattern is reversed in the late 1990s, however, with increased outsourcing activity raising wages compared to an alternative scenario where no outsourcing had taken place.

\section{Conclusion}

This paper adds to the literature on the implications of outsourcing for labour markets by investigating the effect of international outsourcing, measured in terms of imports of intermediates, on wages for different skill groups. To the best of our knowledge, this is the first paper to use individual level data to look at this issue. Our results show that outsourcing has a marked impact on wages. We find evidence of a negative effect of outsourcing on the real wage for low-skilled workers. We also find evidence that high-skilled workers gain from outsourcing in terms of receiving higher wages. These results are robust to a number of different specifications and definitions of outsourcing.

This suggests that low-skilled workers are the losers from this form of globalisation of production, while high-skilled workers are, on average, the group that may be able to gain. This has implications for policy makers, who need to debate whether losers should be compensated or in any other way be the focus of policies aimed at easing the adjustment cost of globalisation. 


\section{References}

Abraham, Katharine G. and Susan N. Houseman, "Earnings Inequality in Germany," in Richard B. Freeman and Lawrence F. Katz, eds., Differences and Changes in Wage Structures, Chicago and London: The University of Chicago Press, 1995, pp. 371-403.

Anderton, Bob and Paul Brenton, "Outsourcing and Low-Skilled Workers in the UK," Bulletin of Economic Research, 1999, 51 (4), 267-285.

Arndt, Sven W., "Globalization and the Open Economy," North American Journal of Economics and Finance, 1997, 8 (1), 71-79.

— , "Globalization and economic development," The Journal of International Trade and Economic Development, 1999, 8 (3), 309-318.

Beaudry, Paul and David Green, "The Changing Structure of Wages in the US and Germany: What Explains the Difference," Working Paper 7697, NBER 2000.

Berman, Eli, John Bound, and Stephen Machin, "Implications of Skill-Biased Technological Change: International Evidence," Quarterly Journal of Economics, 1998, 113 (4), 1245-1280.

Brown, Charles and James Medoff, "The Employer Size-Wage Effect," Journal of Political Economy, 1989, 97 (5), 1027-1059.

Burda, Michael C. and Antje Mertens, "Estimating wage losses of displaced workers in Germany," Labour Economics, 2001, 8 (1).

Falk, Martin and Bertrand M. Koebel, "Outsourcing, Imports and Labour Demand," Scandinavian Journal of Economics, 2002, 104 (4), 567-586.

Feenstra, Robert C., "Integration of Trade and Disintegration of Production in the Global Economy," Journal of Economic Perspectives, 1998, 12 (4), 31-50.

- and Gordon H. Hanson, "Foreign Direct Investment, Outsourcing and Relative Wages," in Robert C. Feenstra, Gene M. Grossman, and D. A. Irwin, eds., The Political Economy of Trade Policy: Papers in Honor of Jagdish Bhagwati, Cambridge, Massechusetts: MIT Press, 1996, pp. 89-127.

- and - , "The impact of outsourcing and high-technology capital on wages: estimates for the United States, 1979-1990," Quarterly Journal of Economics, 
1999, $114(3), 907-940$.

- and - , "Global production sharing and rising inequality: A survey of trade and wages," Working Paper 8372, NBER 2001.

Fitzenberger, Bernd, "International Trade and the Skill Structure of Wages and Employment in West Germany," Jahrbücher für Nationalökonomie und Statistik, 1999, $219(1+2), 67-89$.

Freeman, Richard B., "Are Your Wages Set in Beijing?," Journal of Economic Perspectives, 1995, 9 (3), 15-32.

- and Lawrence F. Katz, "Introduction and Summery," in Richard B. Freeman and Lawrence F. Katz, eds., Differences and Changes in Wage Structures, Chicago and London: The University of Chicago Press, 1995, pp. 1-22.

Frick, Joachim R. and Markus M. Grabka, "Imputation of Item-Non-Response on Income Questions in the SOEP 19842002," Research Notes 29, DIW 2003.

Geishecker, Ingo, "Outsourcing and the Demand for Low-skilled Labour in German Manufacturing: New Evidence," Discussion Paper 313, DIW Berlin 2002 .

Haisken-DeNew, John P. and Joachim R. Frick, "Desktop Companion to the German Socio-Economic Panel," Manual, Available at http://www.diw.de/deutsch/sop/service/dtc/dtc.pdf, DIW Berlin 2003.

- and Klaus F. Zimmermann, "Wage and mobility effects of trade and migration," in Mathias Dewatripont, Andre Sapir, and Khalid Sekkat, eds., Trade and jobs in Europe: Much ado about nothing?, Oxford: Oxford University Press, 1999, pp. 139-160.

Harris, Richard G., "A Communication-Based Model of Global Production Fragmentation," in Sven W. Arndt and Henryk Kierzkowski, eds., Fragmentation: New Production Patterns in teh World Economy, Oxford: University Press, 2001, pp. 52-75.

Head, Keith and John Ries, "Offshore production and skill upgrading by Japanese manufacturing firms," Journal of International Economics, 2002, 58 (1), 81-105. 
Hijzen, Alexander, "Fragmentation, productivity and relative wages in the UK: A mandated wage approach," GEP Research Paper 03/17, University of Nottingham 2003.

— , Holger Görg, and Robert C. Hine, "International fragmentation and relative wages in the UK," Discussion Paper 717, IZA Bonn 2002.

Hsieh, Chang-Tai and Keong T. Woo, "The impact of outsourcing to China on Hong Kong's Labor Market," mimeo, University of California at Berkeley 2003.

Hummels, David, Jun Ishii, and Kei-Mu Yi, "The nature and growth of vertical specialization in worlde trade," Journal of International Economics, $2001,54,75-96$.

Hunt, Jennifer, "Post-Unification Wage Growth in East Germany," The Review of Economics and Statistics, 2001, 83 (1), 190-195.

Jones, Ronald W. and Henryk Kierzkowski, "A Framework for Fragmentation," in Sven W. Arndt and Henryk Kierzkowski, eds., Fragmentation: New Production Patterns in the World Economy, Oxford: University Press, 2001, pp. 17-34.

Kohler, Wilhelm, "Aspects of International Fragmentation," Review of International Economics, 2003, forthcoming.

- , "International Outsourcing and Factor Prices With Multistage Production," Economic Journal, 2004, forthcoming.

Krueger, Alan B. and Jörn-Steffen Pischke, "A Comparative Analysis of East and West German Labor Markets: Before and After Unification," in Richard Freeman and Lawrence Katz, eds., Differences and Changes in Wage Structures, Chicago and London: The University of Chicago Press, 1995.

Krugman, Paul, "Growing World Trade: Causes and Consequences," Brookings Papers on Economic Activity, 1995, (1), 327-377.

Leamer, Edward E., "In Search of Stolper-Samuelson Linkages between International Trade and Lower Wages," in Susan Collins, ed., Imports, Exports and teh American Worker, Washington D.C.: Brookings Institution Press, 1998, pp. 141-203.

Machin, Stephen and John Van Reenen, "Technology and changes in skill 
structure: Evidence from seven OECD countries," Quarterly Journal of Economics, 1998, 113 (4), 1215-1244.

Mincer, Jacob, Schooling, Experience and Earnings, New York: National Bureau of Economic Research, 1974.

Morrison-Paul, Catherine J. and Donald S. Siegel, "The Impacts of Technology, Trade and Outsourcing on Employment and Labor Composition," Scandinavian Journal of Economics, 2001, 103 (2), 241-264.

Moulton, Brent R., "An illustration of the pitfall in estimating the effects of aggregate variables in micro units," The Review of Economics and Statistics, 1990, (72), 334-338.

OECD, Job Study, Part 1, Paris: OECD, 1994.

Prasad, Eswar S., "The Unbearable Stability of the German Wage Structure: Evidence and Interpretation," Working Paper 00/22, IMF 2000.

Reinberg, Alexander and Markus Hummel, "Qualifikationsspezifische Arbeitslosenquoten - reale Entwicklung oder statistisches Artefakt?,"

Werkstattbericht 4, Institut fr Arbeitsmarkt und Berufsforschung 2002.

Schmidt, Christoph M and Klaus F. Zimmermann, "Work Characteristics, Firm Size and Wages," Review of Economics and Statistics, 1991, 73 (4), $705-710$.

UNESCO, "International Standard Classification of Education," Technical Report, UNESCO 1997.

Venables, Anthony J., "Fragmentation and Multinational Production," European Economic Review, 1999, 43 (4-6), 935-945.

Wood, Adrian, "Globalisation and Wage Inequalities: A Synthesis of Three Theories," Weltwirtschaftliches Archiv, 2002, 138 (1), 54-82.

Wooldridge, Jeffrey M., Econometric Analysis of Cross Section and Panel Data, Cambridge, Massachusetts: The MIT Press, 2002. 


\section{A Graphs}

Figure 1: Outsourcing in German Manufacturing Industry

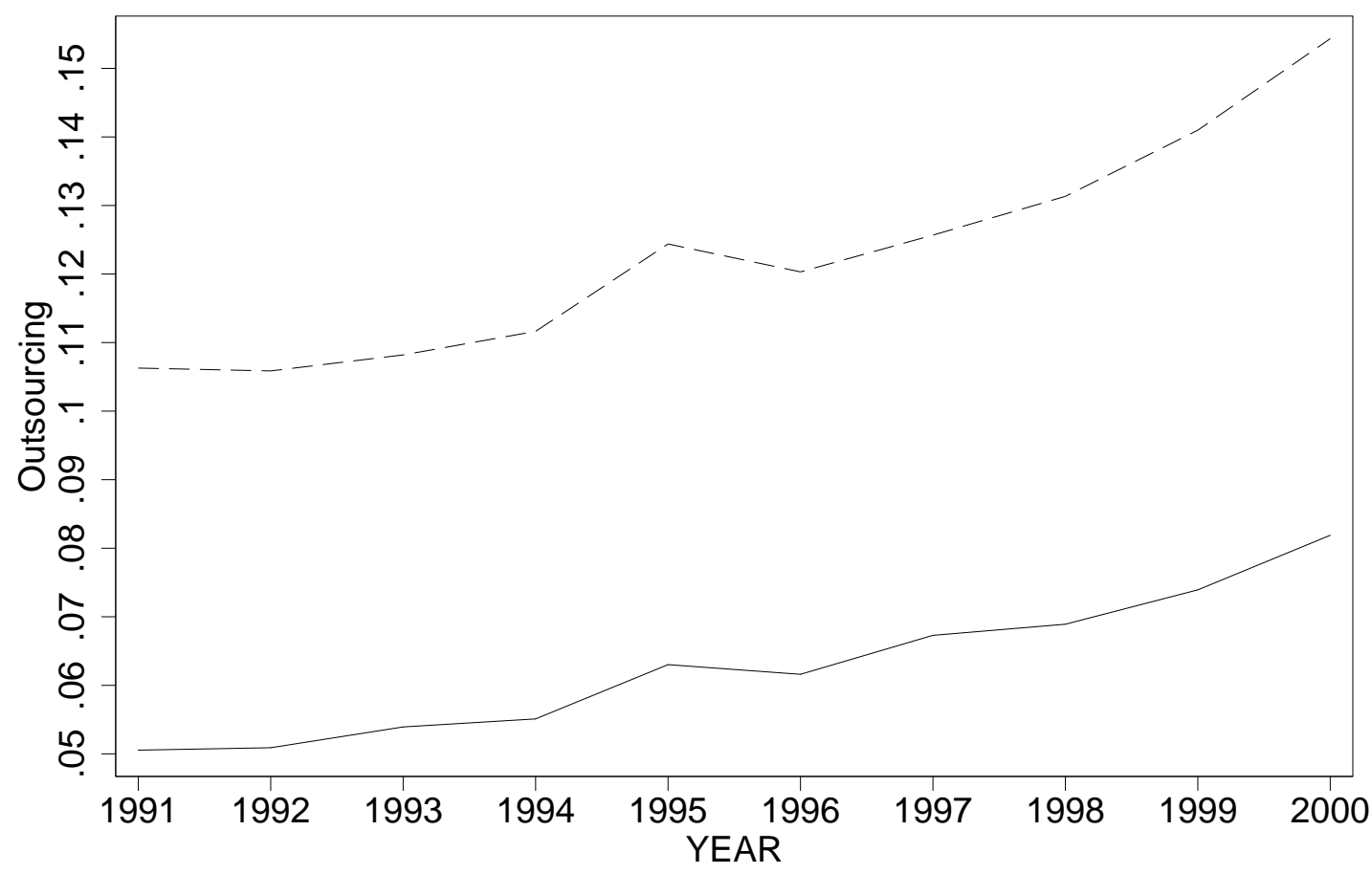

narrow Outsourcing $\quad-----$ wide Outsourcing 
Figure 2: Outsourcing by Industry

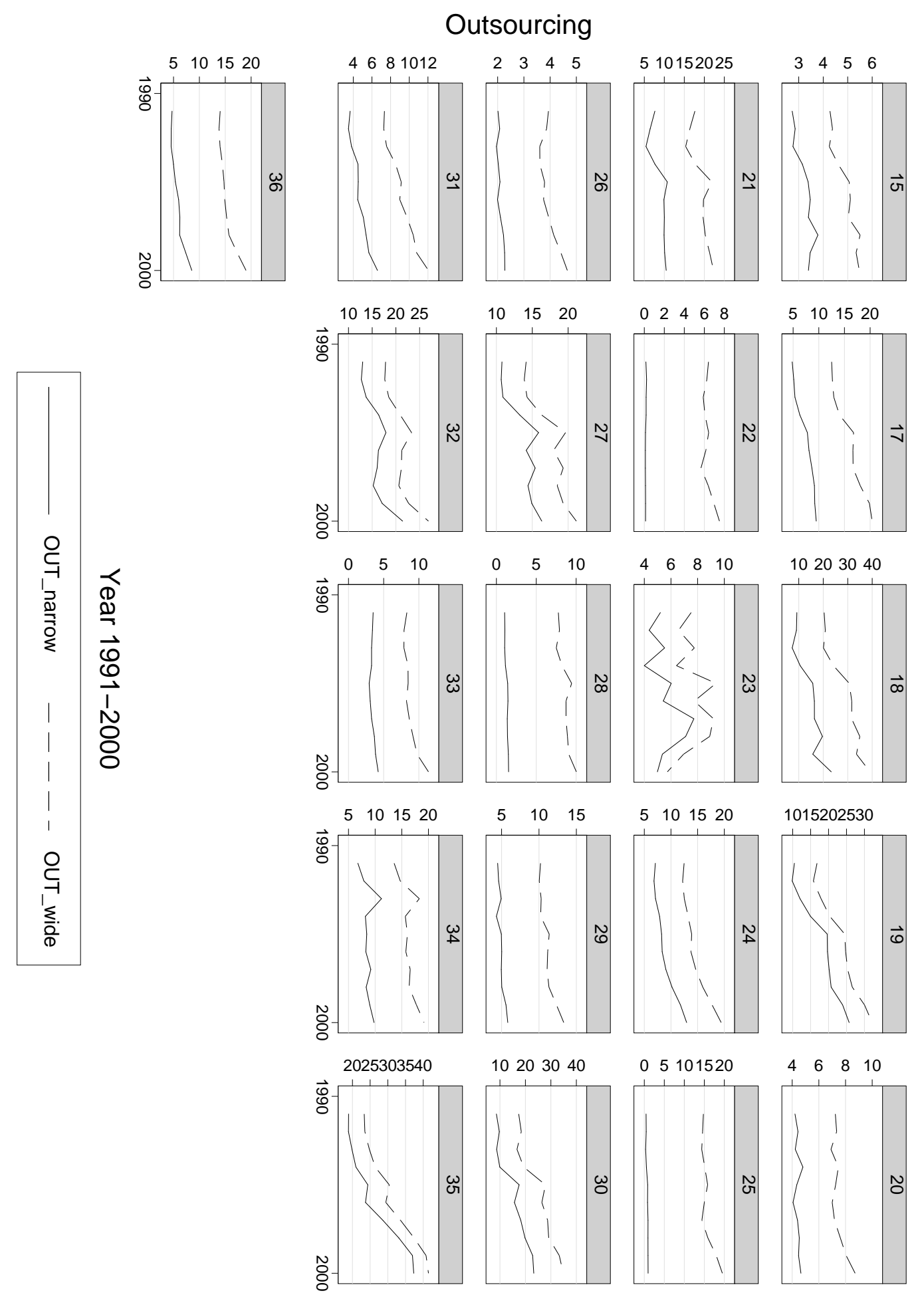


Figure 3: Wage Simulation for high-skilled worker with narrow Outsourcing

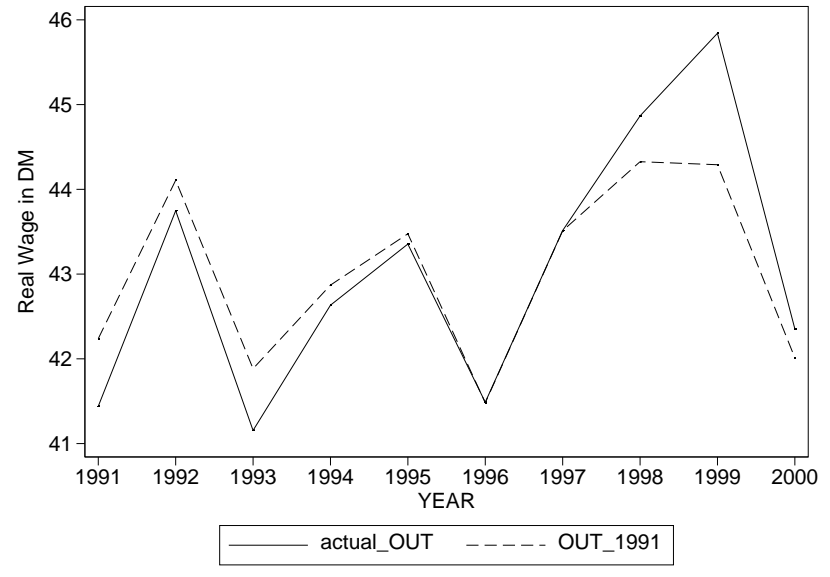

Figure 4: Wage Simulation for high-skilled worker with wide Outsourcing

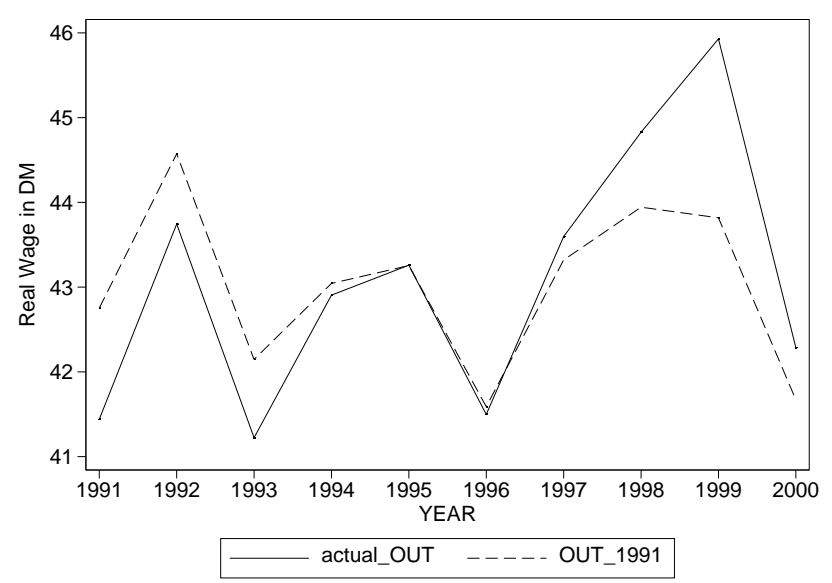

Figure 5: Wage Simulation for medium-skilled worker with wide Outsourcing

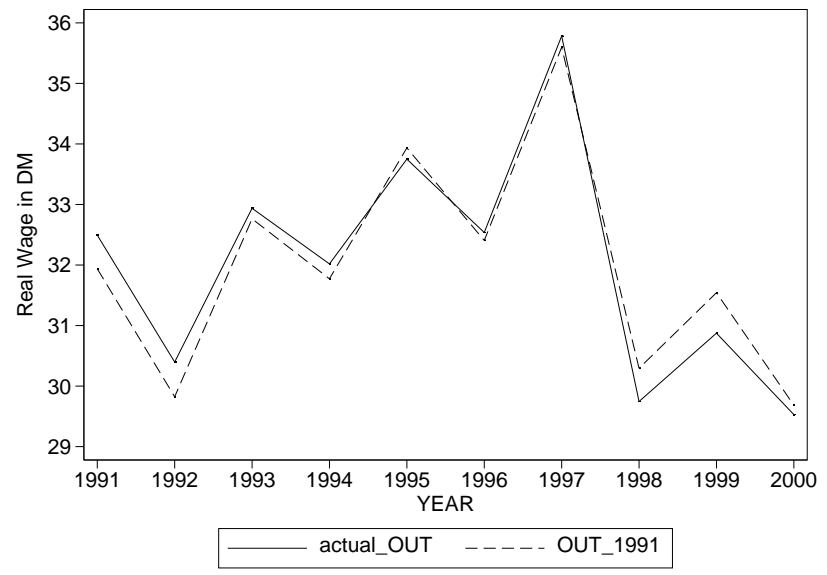


Figure 6: Wage Simulation for ISCED high-skilled worker with narrow Outsourcing

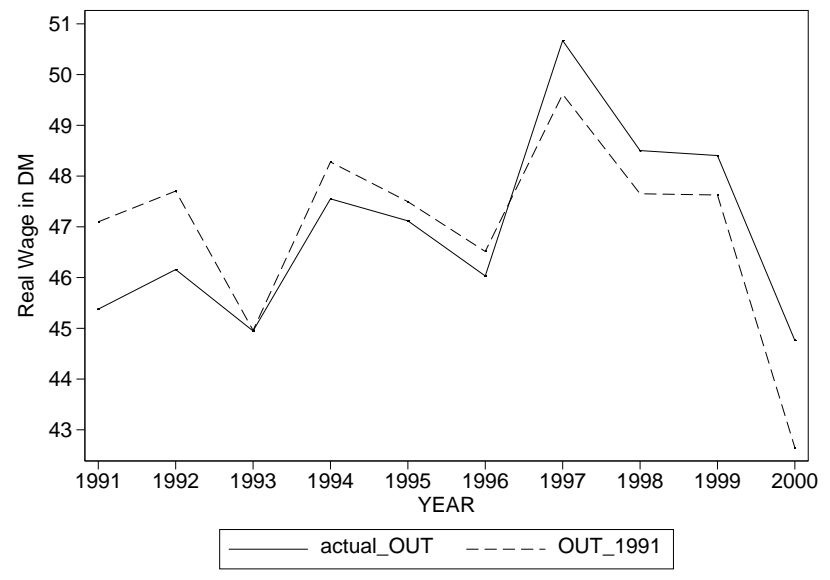

Figure 7: Wage Simulation for ISCED low-skilled worker with narrow Outsourcing

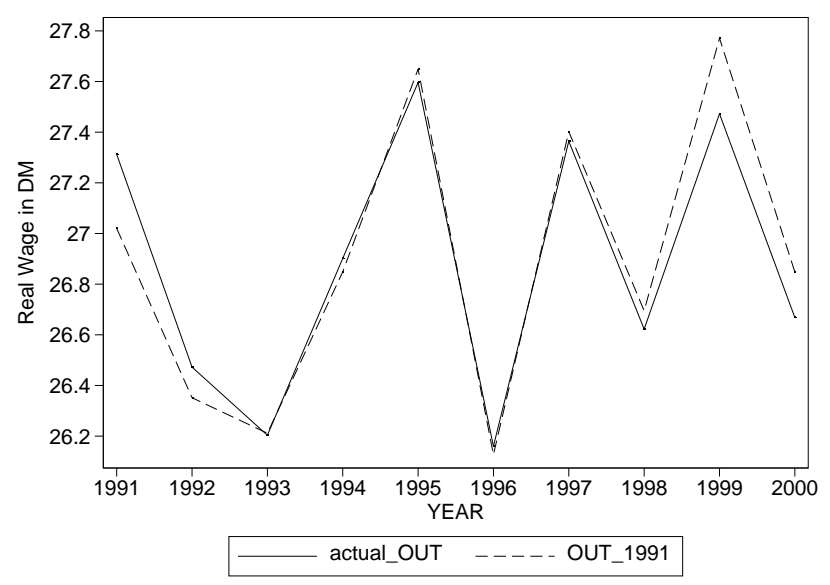

Figure 8: Wage Simulation for ISCED high-skilled worker with wide Outsourcing

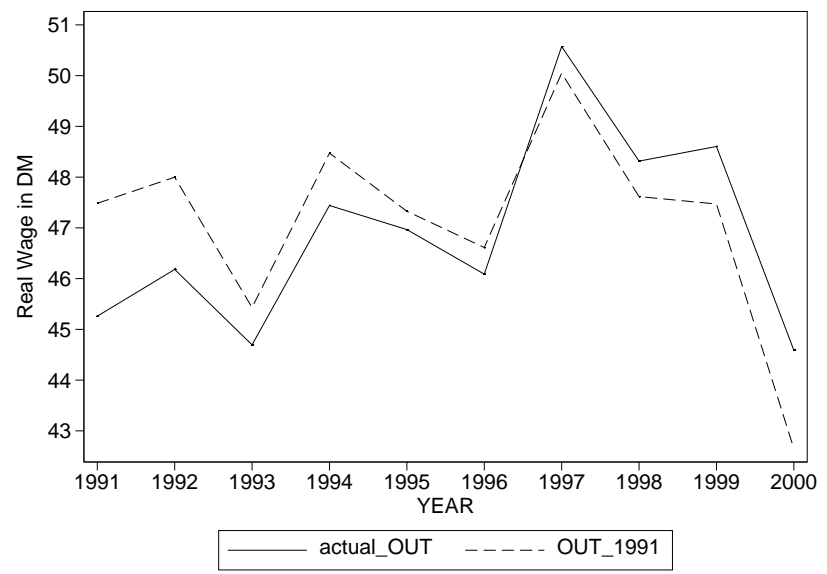


Figure 9: Wage Simulation for ISCED low-skilled worker with wide Outsourcing

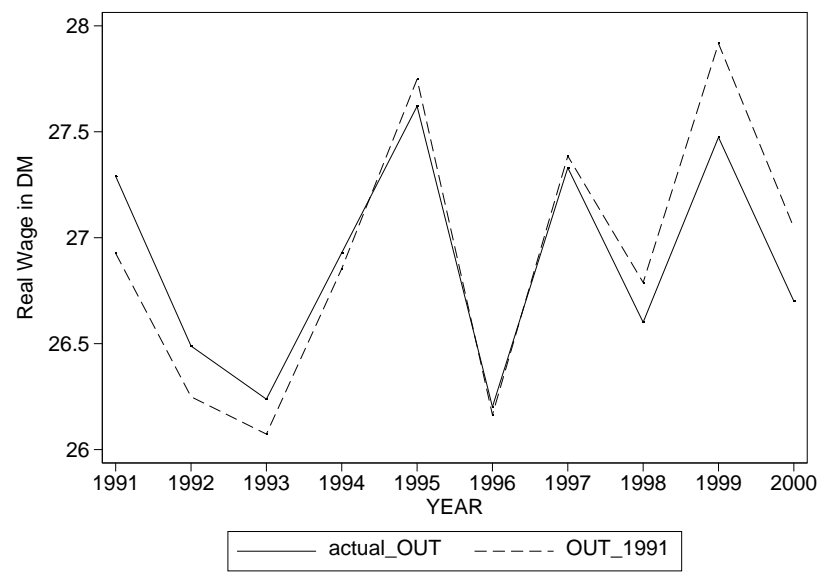

Figure 10: Wage Simulation for worker with high skill requirements with narrow Outsourcing

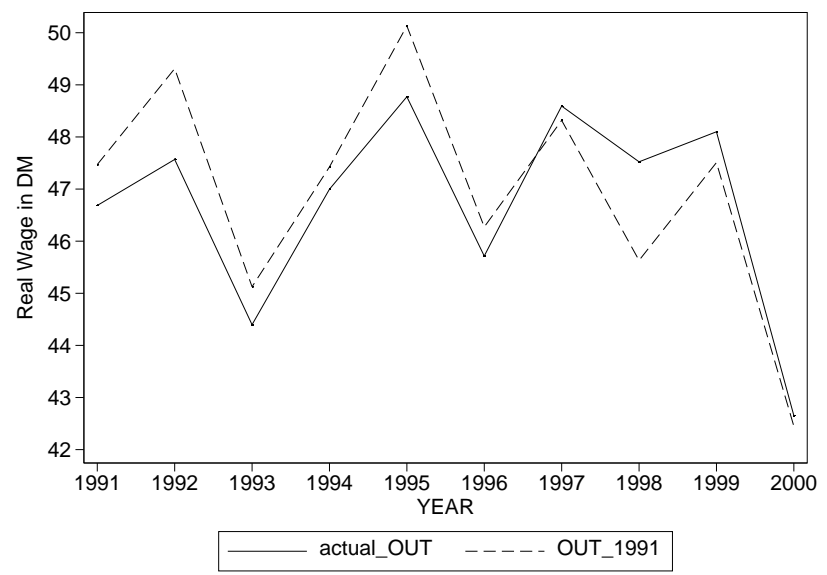

Figure 11: Wage Simulation for worker with low skill requirements with narrow Outsourcing

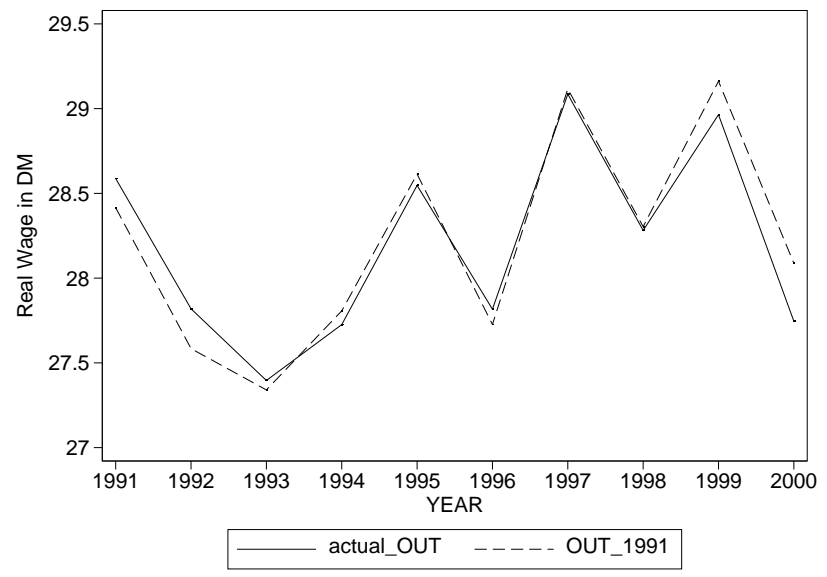


Figure 12: Wage Simulation for worker with high skill requirements with wide Outsourcing

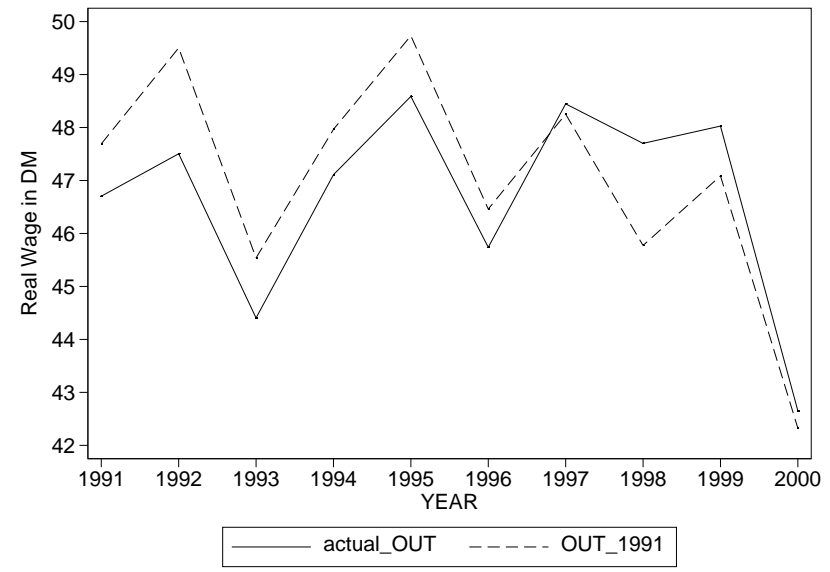

Figure 13: Wage Simulation for worker with low skill requirements with wide Outsourcing

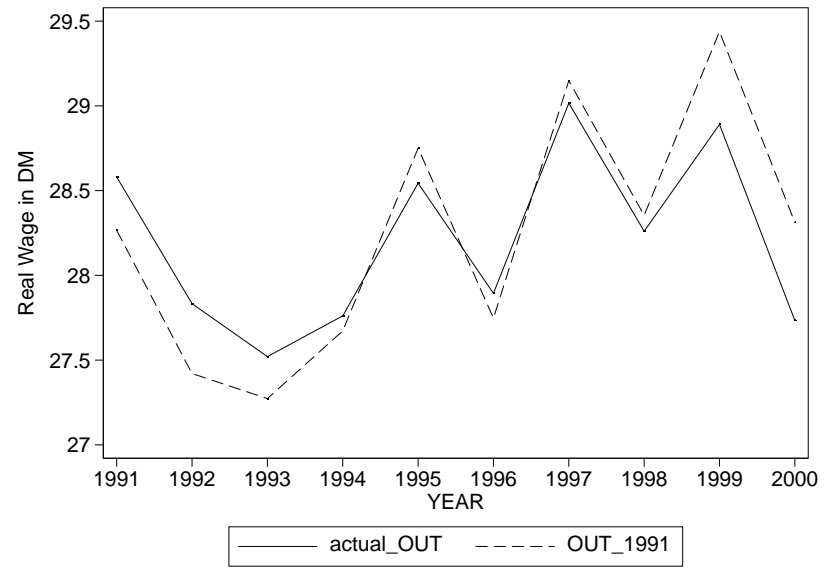




\title{
B Tables
}

Table 1: Alternative skill classifications

\author{
1) Educational Attainment \\ low skill no degree \\ no degree + occupational training \\ lower school degree \\ lower school degree + additional occupational training \\ intermediary school \\ medium skill lower school degree + technical school \\ intermediary school + additional occupational training \\ degree for professional college \\ high school degree \\ high skill high school + additional occupational training \\ degree of professional college + additional occupational training \\ higher technical college \\ University degree
}

2) International Standard Classification of Education (ISCED)

low skill Lower secondary education, Second stage of basic education

medium skill Upper secondary education, Post-secondary non tertiary education, first stage of tertiary education

high skill Second stage of tertiary education

3) Required Qualification

low skill work requires less than technical college or university degree

high skill work requires technical college or university degree 
Table 2: Employment shares and skill* structure of industries in \%

\begin{tabular}{lllll}
\hline & $\begin{array}{l}\text { Employment Share } \\
\text { of industry }\end{array}$ & High-skilled & $\begin{array}{c}\text { Medium-skilled } \\
\text { within industry }\end{array}$ & Low-skilled \\
Food products, beverages, tobaco & 6.24 & 14.46 & 29.46 & 56.08 \\
Textiles & 1.80 & 10.97 & 38.08 & 50.95 \\
Wearing apparel & 0.32 & 10.00 & 18.33 & 71.67 \\
Tanning,dressing of leather & 0.46 & 0.00 & 25.83 & 74.17 \\
Wood products, except furniture & 1.84 & 12.30 & 19.98 & 67.72 \\
Pulp, paper and paper products & 1.66 & 7.62 & 25.37 & 67.01 \\
Publishing, printing and reproduction & 2.97 & 29.21 & 39.10 & 31.69 \\
Coke, refined petroleum & 0.56 & 21.67 & 37.04 & 41.30 \\
Chemicals and chemical products & 13.05 & 25.44 & 29.10 & 45.47 \\
Rubber and plastic products & 2.93 & 10.75 & 35.58 & 53.67 \\
Other non-metallic mineral products & 3.23 & 2.26 & 42.44 & 55.30 \\
Basic metals & 3.44 & 12.22 & 23.96 & 63.82 \\
Fabricated metal products & 20.79 & 13.00 & 30.59 & 56.41 \\
Machinery and equipment & 11.77 & 25.33 & 39.00 & 35.67 \\
Office machinery and computer & 0.29 & 37.50 & 8.33 & 54.17 \\
Electrical machinery and apparatus & 8.18 & 39.90 & 31.28 & 28.82 \\
Radio, television and communication & 1.75 & 41.54 & 35.00 & 23.46 \\
Medical, precision and optical instruments & 2.97 & 26.51 & 52.47 & 21.03 \\
Motor vehicles, trailers & 12.61 & 23.58 & 28.13 & 48.29 \\
Other transport equipment & 1.58 & 25.10 & 41.44 & 33.46 \\
Furniture; manufacturing n.e.c. & 1.74 & 6.03 & 38.55 & 55.42 \\
\end{tabular}

*applying the first skill definition from Table 1 
Table 3: Fixed Effects Log Wage Regression for Fragmentation

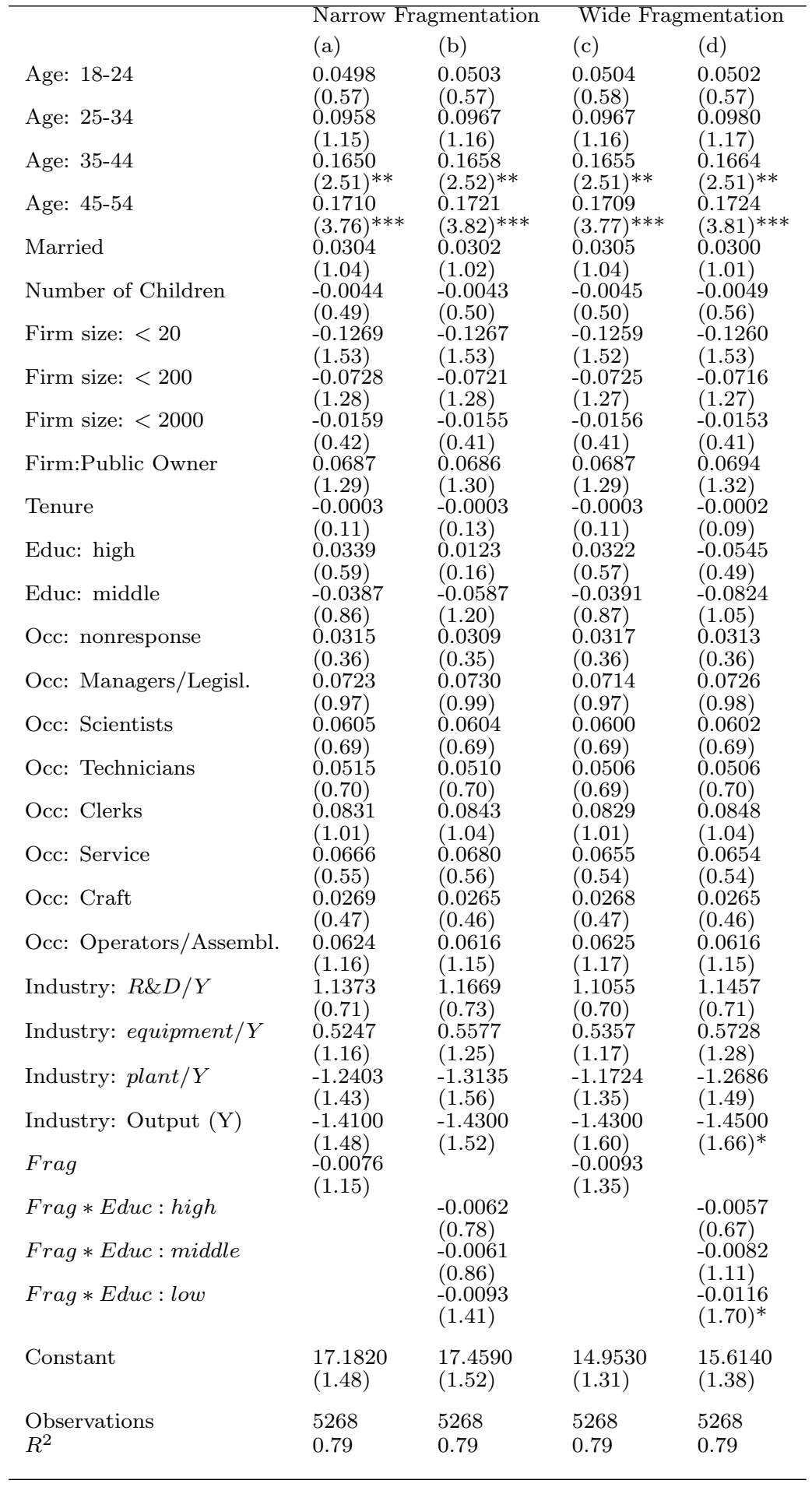

t-statistics in parentheses $*$ significant at $10 \%, * *$ at $5 \%, * * *$ at $1 \%$

not reported: full set of federal state dummies, year dummies, industry dummies and industry specific time trends; default categories: Firm size:> 2000; Occ:Elementary; Low Education; IndustryOutput $* 10^{12}$ 
Table 4: Fixed Effects Log Wage Regression for Outsourcing by Educational Attainment

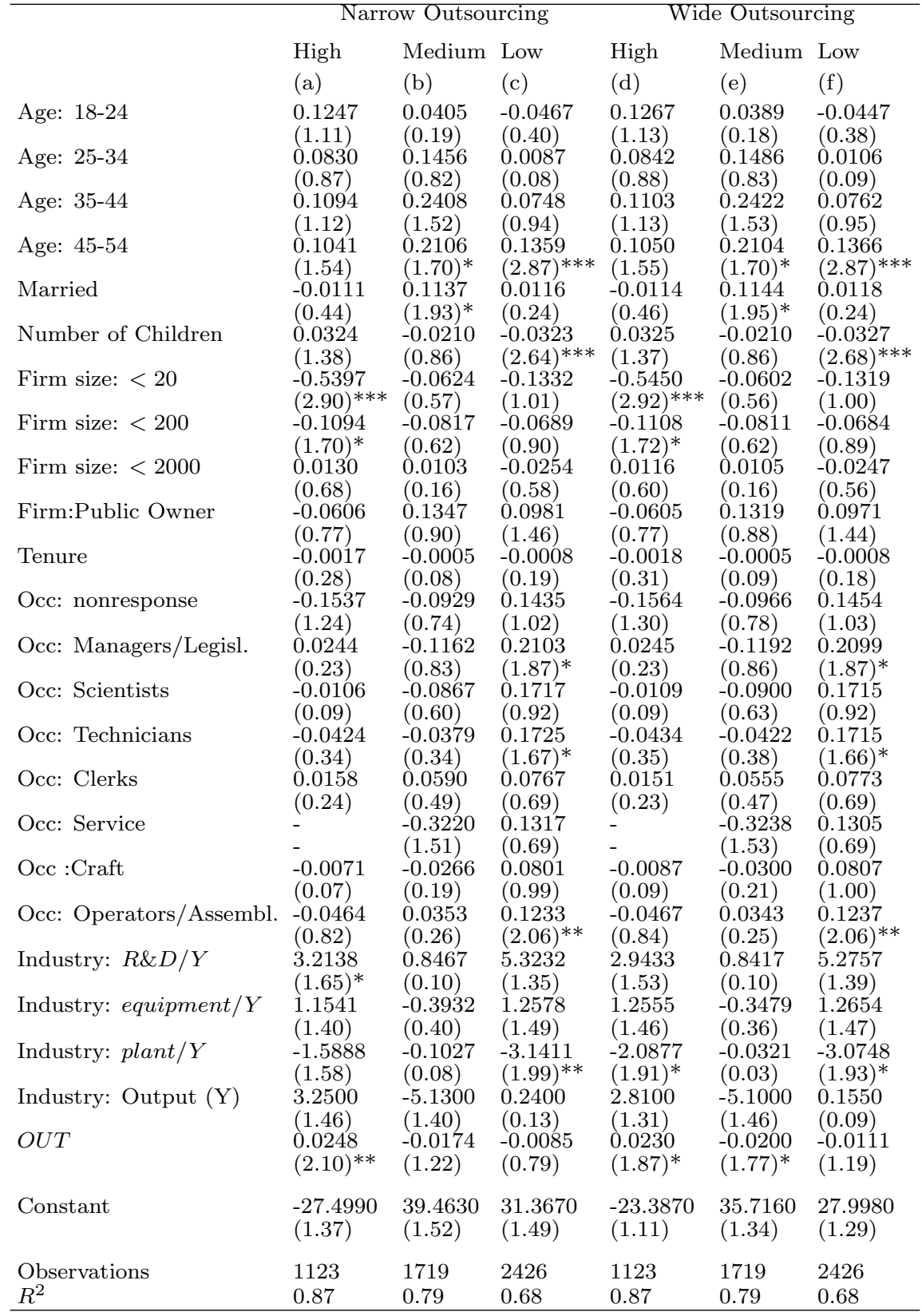

t-statistics in parentheses $*$ significant at $10 \%,{ }^{* *}$ at $5 \%,{ }^{* * *}$ at $1 \%$

not reported: full set of federal state dummies, year dummies, industry dummies and industry specific time trends; default categories: Firm size: $>2000$, Occ:Elementary; IndustryOutput $* 10^{12}$ 
Table 5: Fixed Effects Log Wage Regression for Outsourcing by ISCED Skill Groups

\begin{tabular}{|c|c|c|c|c|c|c|}
\hline & \multicolumn{3}{|c|}{ Narrow Outsourcing } & \multicolumn{3}{|c|}{ Wide Outsourcing } \\
\hline & $\begin{array}{l}\text { High } \\
\text { (a) }\end{array}$ & $\begin{array}{l}\text { Medium } \\
\text { (b) }\end{array}$ & $\begin{array}{l}\text { Low } \\
\text { (c) }\end{array}$ & $\begin{array}{l}\text { High } \\
\text { (d) }\end{array}$ & $\begin{array}{l}\text { Medium } \\
\text { (e) }\end{array}$ & $\begin{array}{l}\text { Low } \\
\text { (f) }\end{array}$ \\
\hline Age: $18-24$ & $\begin{array}{l}0.2671 \\
(1.77)^{*}\end{array}$ & $\begin{array}{l}0.3546 \\
(1.64)\end{array}$ & $\begin{array}{l}-0.0116 \\
(0.09)\end{array}$ & $\begin{array}{l}0.2750 \\
(1.81)^{*}\end{array}$ & $\begin{array}{l}0.3556 \\
(1.63)\end{array}$ & $\begin{array}{l}-0.0108 \\
(0.09)\end{array}$ \\
\hline Age: $25-34$ & $\begin{array}{l}0.2117 \\
(1.84)^{*}\end{array}$ & $\begin{array}{l}0.1304 \\
(0.80)\end{array}$ & $\begin{array}{l}0.0550 \\
(0.47)\end{array}$ & $\begin{array}{l}0.2140 \\
(1.86)^{*}\end{array}$ & $\begin{array}{l}0.1321 \\
(0.80)\end{array}$ & $\begin{array}{l}0.0562 \\
(0.48)\end{array}$ \\
\hline Age: $35-44$ & $\begin{array}{l}0.2113 \\
(2.00)^{* *}\end{array}$ & $\begin{array}{l}0.2543 \\
(1.58)\end{array}$ & $\begin{array}{l}0.1133 \\
(1.46)\end{array}$ & $\begin{array}{l}0.2136 \\
(2.02)^{* *}\end{array}$ & $\begin{array}{l}0.2556 \\
(1.58)\end{array}$ & $\begin{array}{l}0.1140 \\
(1.47)\end{array}$ \\
\hline Age: $45-54$ & $\begin{array}{l}0.1459 \\
(1.96)^{*}\end{array}$ & $\begin{array}{l}0.2453 \\
(1.78)^{*}\end{array}$ & $\begin{array}{l}0.1481 \\
(3.40)^{* * *}\end{array}$ & $\begin{array}{l}0.1484 \\
(1.97)^{* *}\end{array}$ & $\begin{array}{l}0.2461 \\
(1.77)^{*}\end{array}$ & $\begin{array}{l}0.1482 \\
(3.42) * * *\end{array}$ \\
\hline Married & $\begin{array}{l}-0.0087 \\
(0.26)\end{array}$ & $\begin{array}{l}0.1382 \\
(1.92)^{*}\end{array}$ & $\begin{array}{l}0.0136 \\
(0.33)\end{array}$ & $\begin{array}{l}-0.0101 \\
(0.32)\end{array}$ & $\begin{array}{l}0.1383 \\
(1.92)^{*}\end{array}$ & $\begin{array}{l}0.0139 \\
(0.34)\end{array}$ \\
\hline Number of Children & $\begin{array}{l}0.0374 \\
(1.36)\end{array}$ & $\begin{array}{l}-0.0462 \\
(1.15)\end{array}$ & $\begin{array}{l}-0.0146 \\
(1.53)\end{array}$ & $\begin{array}{l}0.0373 \\
(1.34)\end{array}$ & $\begin{array}{l}-0.0460 \\
(1.14)\end{array}$ & $\begin{array}{l}-0.0148 \\
(1.55)\end{array}$ \\
\hline Firm size: $<20$ & $\begin{array}{l}-0.5178 \\
(2.74) * * *\end{array}$ & $\begin{array}{l}-0.0351 \\
(0.28)\end{array}$ & $\begin{array}{l}-0.0995 \\
(0.85)\end{array}$ & $\begin{array}{l}-0.5207 \\
(2.76)^{* * *}\end{array}$ & $\begin{array}{l}-0.0347 \\
(0.28)\end{array}$ & $\begin{array}{l}-0.0981 \\
(0.84)\end{array}$ \\
\hline Firm size: $<200$ & $\begin{array}{l}-0.0882 \\
(1.53)\end{array}$ & $\begin{array}{l}-0.0409 \\
(0.59)\end{array}$ & $\begin{array}{l}-0.0624 \\
(0.81)\end{array}$ & $\begin{array}{l}-0.0890 \\
(1.54)\end{array}$ & $\begin{array}{l}-0.0418 \\
(0.61)\end{array}$ & $\begin{array}{l}-0.0619 \\
(0.80)\end{array}$ \\
\hline Firm size: $<2000$ & $\begin{array}{l}-0.0073 \\
(0.24)\end{array}$ & $\begin{array}{l}-0.0345 \\
(0.45)\end{array}$ & $\begin{array}{l}0.0112 \\
(0.24)\end{array}$ & $\begin{array}{l}-0.0075 \\
(0.24)\end{array}$ & $\begin{array}{l}-0.0348 \\
(0.46)\end{array}$ & $\begin{array}{l}0.0117 \\
(0.25)\end{array}$ \\
\hline Firm:Public Owner & $\begin{array}{l}0.0405 \\
(0.32)\end{array}$ & $\begin{array}{l}0.0553 \\
(0.34)\end{array}$ & $\begin{array}{l}0.0924 \\
(1.34)\end{array}$ & $\begin{array}{l}0.0435 \\
(0.34)\end{array}$ & $\begin{array}{l}0.0577 \\
(0.35)\end{array}$ & $\begin{array}{l}0.0915 \\
(1.33)\end{array}$ \\
\hline Tenure & $\begin{array}{l}0.0001 \\
(0.05)\end{array}$ & $\begin{array}{l}-0.0023 \\
(0.61)\end{array}$ & $\begin{array}{l}0.0003 \\
(0.09)\end{array}$ & $\begin{array}{l}0.0001 \\
(0.06)\end{array}$ & $\begin{array}{l}-0.0023 \\
(0.60)\end{array}$ & $\begin{array}{l}0.0003 \\
(0.09)\end{array}$ \\
\hline Occ: nonresponse & $\begin{array}{l}-0.0505 \\
(0.60)\end{array}$ & $\begin{array}{l}-0.0682 \\
(0.84)\end{array}$ & $\begin{array}{l}0.0852 \\
(0.77)\end{array}$ & $\begin{array}{l}0.0000 \\
(.)\end{array}$ & $\begin{array}{l}-0.0684 \\
(0.83)\end{array}$ & $\begin{array}{l}0.0853 \\
(0.77)\end{array}$ \\
\hline Occ: Managers/Legisl. & $\begin{array}{l}0.0028 \\
(0.04)\end{array}$ & $\begin{array}{l}0.0652 \\
(0.61)\end{array}$ & $\begin{array}{l}0.1154 \\
(1.15)\end{array}$ & $\begin{array}{l}0.0531 \\
(0.64)\end{array}$ & $\begin{array}{l}0.0656 \\
(0.62)\end{array}$ & $\begin{array}{l}0.1139 \\
(1.14)\end{array}$ \\
\hline Occ: Scientists & $\begin{array}{l}0.0172 \\
(0.25)\end{array}$ & $\begin{array}{l}-0.0008 \\
(0.01)\end{array}$ & $\begin{array}{l}0.1097 \\
(0.80)\end{array}$ & $\begin{array}{l}0.0699 \\
(1.81)^{*}\end{array}$ & $\begin{array}{l}-0.0012 \\
(0.01)\end{array}$ & $\begin{array}{l}0.1091 \\
(0.79)\end{array}$ \\
\hline Occ: Technicians & $\begin{array}{l}0.0580 \\
(0.53)\end{array}$ & $\begin{array}{l}-0.0495 \\
(0.45)\end{array}$ & $\begin{array}{l}0.1207 \\
(1.36)\end{array}$ & $\begin{array}{l}0.1105 \\
(3.50)^{* * *}\end{array}$ & $\begin{array}{l}-0.0505 \\
(0.46)\end{array}$ & $\begin{array}{l}0.1197 \\
(1.35)\end{array}$ \\
\hline Occ: Clerks & $\begin{array}{l}0.1167 \\
(1.75)^{*}\end{array}$ & $\begin{array}{l}0.1124 \\
(0.83)\end{array}$ & $\begin{array}{l}0.0738 \\
(0.92)\end{array}$ & $\begin{array}{l}0.1674 \\
(1.23)\end{array}$ & $\begin{array}{l}0.1110 \\
(0.82)\end{array}$ & $\begin{array}{l}0.0734 \\
(0.92)\end{array}$ \\
\hline Occ: Service & $\begin{array}{l}0.0000 \\
(.)\end{array}$ & $\begin{array}{l}0.0000 \\
(.)\end{array}$ & $\begin{array}{l}0.0731 \\
(0.50)\end{array}$ & $\begin{array}{l}0.0000 \\
(.)\end{array}$ & $\begin{array}{l}0.0000 \\
(.)\end{array}$ & $\begin{array}{l}0.0711 \\
(0.49)\end{array}$ \\
\hline Occ :Craft & $\begin{array}{l}0.0000 \\
(.)\end{array}$ & $\begin{array}{l}-0.0567 \\
(0.45)\end{array}$ & $\begin{array}{l}0.0777 \\
(1.20)\end{array}$ & $\begin{array}{l}0.0490 \\
(0.60)\end{array}$ & $\begin{array}{l}-0.0561 \\
(0.45)\end{array}$ & $\begin{array}{l}0.0775 \\
(1.20)\end{array}$ \\
\hline Occ: Operators/Assembl. & $\begin{array}{l}-0.0718 \\
(1.16)\end{array}$ & $\begin{array}{l}0.0405 \\
(0.28)\end{array}$ & $\begin{array}{l}0.1029 \\
(1.88)^{*}\end{array}$ & $\begin{array}{l}-0.0694 \\
(1.12)\end{array}$ & $\begin{array}{l}0.0413 \\
(0.28)\end{array}$ & $\begin{array}{l}0.1028 \\
(1.88)^{*}\end{array}$ \\
\hline Industry: $R \& D / Y$ & $\begin{array}{l}1.8011 \\
(0.70)\end{array}$ & $\begin{array}{l}7.8445 \\
(1.07)\end{array}$ & $\begin{array}{l}1.8605 \\
(0.76)\end{array}$ & $\begin{array}{l}1.1796 \\
(0.46)\end{array}$ & $\begin{array}{l}7.5382 \\
(1.05)\end{array}$ & $\begin{array}{l}1.9359 \\
(0.81)\end{array}$ \\
\hline Industry: equipment/Y & $\begin{array}{l}0.4998 \\
(0.33)\end{array}$ & $\begin{array}{l}0.9013 \\
(0.49)\end{array}$ & $\begin{array}{l}0.6951 \\
(1.00)\end{array}$ & $\begin{array}{l}0.7108 \\
(0.46)\end{array}$ & $\begin{array}{l}0.9529 \\
(0.51)\end{array}$ & $\begin{array}{l}0.6928 \\
(0.97)\end{array}$ \\
\hline Industry: plant/Y & $\begin{array}{l}1.0594 \\
(0.50)\end{array}$ & $\begin{array}{l}-2.9889 \\
(1.06)\end{array}$ & $\begin{array}{l}-2.0342 \\
(2.43)^{* *}\end{array}$ & $\begin{array}{l}0.3295 \\
(0.15)\end{array}$ & $\begin{array}{l}-3.0821 \\
(1.12)\end{array}$ & $\begin{array}{l}-1.9453 \\
(2.25) * *\end{array}$ \\
\hline Industry: Output (Y) & $\begin{array}{l}4.4900 \\
(1.84)^{*}\end{array}$ & $\begin{array}{l}-7.0500 \\
(2.09)^{* *}\end{array}$ & $\begin{array}{l}-0.6410 \\
(0.57)\end{array}$ & $\begin{array}{l}3.6500 \\
(1.70)^{*}\end{array}$ & $\begin{array}{l}-7.3100 \\
(2.21)^{* *}\end{array}$ & $\begin{array}{l}-0.5980 \\
(0.54)\end{array}$ \\
\hline$O U T$ & $\begin{array}{l}0.0336 \\
(2.33)^{* *}\end{array}$ & $\begin{array}{l}0.0044 \\
(0.22)\end{array}$ & $\begin{array}{l}-0.0118 \\
(1.72)^{*}\end{array}$ & $\begin{array}{l}0.0275 \\
(2.66)^{* * *}\end{array}$ & $\begin{array}{l}0.0002 \\
(0.01)\end{array}$ & $\begin{array}{l}-0.0127 \\
(2.15)^{* *}\end{array}$ \\
\hline Constant & $\begin{array}{l}-6.7355 \\
(0.52)\end{array}$ & $\begin{array}{l}-92.2060 \\
(1.35)\end{array}$ & $\begin{array}{l}30.6110 \\
(2.11)^{* *}\end{array}$ & $\begin{array}{l}-3.3700 \\
(0.24)\end{array}$ & $\begin{array}{l}-93.4690 \\
(1.41)\end{array}$ & $\begin{array}{l}27.6310 \\
(1.89)^{*}\end{array}$ \\
\hline $\begin{array}{l}\text { Observations } \\
R^{2}\end{array}$ & $\begin{array}{l}891 \\
0.87\end{array}$ & $\begin{array}{l}1004 \\
0.71\end{array}$ & $\begin{array}{l}3369 \\
0.72\end{array}$ & $\begin{array}{l}891 \\
0.87\end{array}$ & $\begin{array}{l}1004 \\
0.71\end{array}$ & $\begin{array}{l}3369 \\
0.72\end{array}$ \\
\hline
\end{tabular}

t-statistics in parentheses * significant at $10 \%, * *$ at $5 \%, * * *$ at $1 \%$

not reported: full set of federal state dummies, year dummies, industry dummies and industry specific time trends; default categories: Firm size: $>2000$; Occ:Elementary; IndustryOutput $* 10^{12}$; For 4 observations of the initial sample ISCED classifications are missing. 
Table 6: Fixed Effects Log Wage Regression by Required Skill

\begin{tabular}{|c|c|c|c|c|}
\hline & \multicolumn{2}{|c|}{ Narrow Outsourcing } & \multicolumn{2}{|c|}{ Wide Outsourcing } \\
\hline & $\begin{array}{l}\text { High } \\
\text { (a) }\end{array}$ & $\begin{array}{l}\text { Low } \\
\text { (b) }\end{array}$ & $\begin{array}{l}\text { High } \\
\text { (c) }\end{array}$ & $\begin{array}{l}\text { Low } \\
\text { (d) }\end{array}$ \\
\hline Age: $18-24$ & - & $\begin{array}{l}0.0623 \\
(0.60)\end{array}$ & $\begin{array}{l}- \\
-\end{array}$ & $\begin{array}{l}0.0644 \\
(0.62)\end{array}$ \\
\hline Age: $25-34$ & $\begin{array}{l}0.0417 \\
(0.43)\end{array}$ & $\begin{array}{l}0.1073 \\
(1.08)\end{array}$ & $\begin{array}{l}0.0448 \\
(0.47)\end{array}$ & $\begin{array}{l}0.1100 \\
(1.10)\end{array}$ \\
\hline Age: $35-44$ & $\begin{array}{l}0.0918 \\
(1.23)\end{array}$ & $\begin{array}{l}0.1736 \\
(2.29)^{* *}\end{array}$ & $\begin{array}{l}0.0946 \\
(1.27)\end{array}$ & $\begin{array}{l}0.1752 \\
(2.30)^{* *}\end{array}$ \\
\hline Age: $45-54$ & $\begin{array}{l}0.0811 \\
(1.47)\end{array}$ & $\begin{array}{l}0.1830 \\
(3.61)^{* * *}\end{array}$ & $\begin{array}{l}0.0825 \\
(1.48)\end{array}$ & $\begin{array}{l}0.1832 \\
(3.61)^{* * *}\end{array}$ \\
\hline Married & $\begin{array}{l}0.0239 \\
(0.56)\end{array}$ & $\begin{array}{l}0.0188 \\
(0.53)\end{array}$ & $\begin{array}{l}0.0241 \\
(0.57)\end{array}$ & $\begin{array}{l}0.0189 \\
(0.53)\end{array}$ \\
\hline Number of Children & $\begin{array}{l}0.0336 \\
(1.37)\end{array}$ & $\begin{array}{l}-0.0242 \\
(2.39)^{* *}\end{array}$ & $\begin{array}{l}0.0330 \\
(1.36)\end{array}$ & $\begin{array}{l}-0.0245 \\
(2.39)^{* *}\end{array}$ \\
\hline Firm size: $<20$ & $\begin{array}{l}-0.5623 \\
(2.71)^{* * *}\end{array}$ & $\begin{array}{l}-0.1149 \\
(1.13)\end{array}$ & $\begin{array}{l}-0.5653 \\
(2.73)^{* * *}\end{array}$ & $\begin{array}{l}-0.1126 \\
(1.11)\end{array}$ \\
\hline Firm size: $<200$ & $\begin{array}{l}-0.0907 \\
(1.42)\end{array}$ & $\begin{array}{l}-0.0841 \\
(1.24)\end{array}$ & $\begin{array}{l}-0.0904 \\
(1.42)\end{array}$ & $\begin{array}{l}-0.0832 \\
(1.22)\end{array}$ \\
\hline Firm size: $<2000$ & $\begin{array}{l}0.0127 \\
(0.51)\end{array}$ & $\begin{array}{l}-0.0206 \\
(0.44)\end{array}$ & $\begin{array}{l}0.0131 \\
(0.52)\end{array}$ & $\begin{array}{l}-0.0197 \\
(0.42)\end{array}$ \\
\hline Firm:Public Owner & $\begin{array}{l}0.0656 \\
(0.50)\end{array}$ & $\begin{array}{l}0.0653 \\
(0.90)\end{array}$ & $\begin{array}{l}0.0663 \\
(0.50)\end{array}$ & $\begin{array}{l}0.0644 \\
(0.89)\end{array}$ \\
\hline Tenure & $\begin{array}{l}-0.0031 \\
(0.79)\end{array}$ & $\begin{array}{l}0.0011 \\
(0.41)\end{array}$ & $\begin{array}{l}-0.0033 \\
(0.81)\end{array}$ & $\begin{array}{l}0.0012 \\
(0.43)\end{array}$ \\
\hline Occ: nonresponse & - & $\begin{array}{l}0.0261 \\
(0.29)\end{array}$ & - & $\begin{array}{l}0.0265 \\
(0.30)\end{array}$ \\
\hline Occ: Managers/Legisl. & $\begin{array}{l}0.2695 \\
(5.12)^{* * *}\end{array}$ & $\begin{array}{l}0.0549 \\
(0.78)\end{array}$ & $\begin{array}{l}0.2748 \\
(5.11)^{* * *}\end{array}$ & $\begin{array}{l}0.0534 \\
(0.77)\end{array}$ \\
\hline Occ: Scientists & $\begin{array}{l}0.3099 \\
(10.06)^{* * *}\end{array}$ & $\begin{array}{l}0.0848 \\
(0.72)\end{array}$ & $\begin{array}{l}0.3147 \\
(9.77)^{* * *}\end{array}$ & $\begin{array}{l}0.0844 \\
(0.72)\end{array}$ \\
\hline Occ: Technicians & $\begin{array}{l}0.3583 \\
(6.44)^{* * *}\end{array}$ & $\begin{array}{l}0.0244 \\
(0.30)\end{array}$ & $\begin{array}{l}0.3614 \\
(6.35)^{* * *}\end{array}$ & $\begin{array}{l}0.0227 \\
(0.28)\end{array}$ \\
\hline Occ: Clerks & $\begin{array}{l}0.2743 \\
(5.14)^{* * *}\end{array}$ & $\begin{array}{l}0.0882 \\
(1.01)\end{array}$ & $\begin{array}{l}0.2773 \\
(5.06)^{* * *}\end{array}$ & $\begin{array}{l}0.0878 \\
(1.01)\end{array}$ \\
\hline Occ: Service & - & $\begin{array}{l}0.0435 \\
(0.40)\end{array}$ & - & $\begin{array}{l}0.0414 \\
(0.38)\end{array}$ \\
\hline Occ : Craft & $\begin{array}{l}0.2558 \\
(6.34)^{* * *}\end{array}$ & $\begin{array}{l}0.0152 \\
(0.27)\end{array}$ & $\begin{array}{l}0.2601 \\
(6.09)^{* * *}\end{array}$ & $\begin{array}{l}0.0150 \\
(0.27)\end{array}$ \\
\hline Occ: Operators/Assembl. & $\begin{array}{l}0.0000 \\
(.)\end{array}$ & $\begin{array}{l}0.0529 \\
(1.02)\end{array}$ & $\begin{array}{l}0.0000 \\
(.)\end{array}$ & $\begin{array}{l}0.0531 \\
(1.02)\end{array}$ \\
\hline Industry: $R \& D / Y$ & $\begin{array}{l}2.3766 \\
(1.17)\end{array}$ & $\begin{array}{l}2.9769 \\
(0.70)\end{array}$ & $\begin{array}{l}2.1834 \\
(1.10)\end{array}$ & $\begin{array}{l}2.9897 \\
(0.70)\end{array}$ \\
\hline Industry: equipment/Y & $\begin{array}{l}1.9508 \\
(1.88)^{*}\end{array}$ & $\begin{array}{l}0.3860 \\
(0.67)\end{array}$ & $\begin{array}{l}2.0508 \\
(1.87)^{*}\end{array}$ & $\begin{array}{l}0.4090 \\
(0.71)\end{array}$ \\
\hline Industry: plant/Y & $\begin{array}{l}-4.4802 \\
(2.13)^{* *}\end{array}$ & $\begin{array}{l}-2.2134 \\
(1.35)\end{array}$ & $\begin{array}{l}-5.0401 \\
(2.17)^{* *}\end{array}$ & $\begin{array}{l}-2.1452 \\
(1.31)\end{array}$ \\
\hline Industry: Output (Y) & $\begin{array}{l}2.7900 \\
(1.41)\end{array}$ & $\begin{array}{l}-1.8700 \\
(1.06)\end{array}$ & $\begin{array}{l}2.4200 \\
(1.27)\end{array}$ & $\begin{array}{l}-1.8800 \\
(1.10)\end{array}$ \\
\hline OUT & $\begin{array}{l}0.0237 \\
(1.88)^{*}\end{array}$ & $\begin{array}{l}-0.0151 \\
(2.16)^{* *}\end{array}$ & $\begin{array}{l}0.0222 \\
(1.94)^{*}\end{array}$ & $\begin{array}{l}-0.0176 \\
(2.68)^{* * *}\end{array}$ \\
\hline Constant & $\begin{array}{l}-4.7906 \\
(0.28)\end{array}$ & $\begin{array}{l}18.2330 \\
(1.36)\end{array}$ & $\begin{array}{l}-2.0152 \\
(0.12)\end{array}$ & $\begin{array}{l}14.1410 \\
(1.06)\end{array}$ \\
\hline Observations & 892 & 4332 & 892 & 4332 \\
\hline$R^{2}$ & 0.83 & 0.73 & 0.83 & 0.73 \\
\hline
\end{tabular}

t-statistics in parentheses $*$ significant at $10 \%,{ }^{* *}$ at $5 \%,{ }^{* * *}$ at $1 \%$

not reported: full set of federal state dummies, year dummies, industry dummies and industry specific time trends; default categories: Firm size: $>2000$; Occ:Elementary; IndustryOutput $* 10^{12}$; For 44 observations of the initial sample information on required qualification is missing. 